\title{
METACOGNITIVE AWARENESS AND SELF-EFFICACY: DO THEY CONTRIBUTE TO INDONESIAN EFL STUDENTS' LISTENING COMPREHENSION ACHIEVEMENT?
}

\author{
Chothibul Umam $^{1 *}$, Moh. Ana Ushuludin ${ }^{2}$, Ary Setya Budhi Ningrum ${ }^{3}$, Burhanudin Syaifulloh $^{4}$, Dewi Nur Suci ${ }^{5}$ \\ $1^{* * 2,2,3,4,5}$ Institut Agama Islam Negeri (IAIN) Kediri, Indonesia. \\ Email: ${ }^{1 *}$ chothib99@iainkediri.ac.id, ${ }^{2}$ anauboys@gmail.com, ${ }^{3}$ ary_oyesip@yahoo.com, ${ }^{4}$ hanspct@gmail.com, \\ 5 dewinursuci@gmail.com
}

Article History: Received on $3^{\text {rd }}$ January 2020, Revised on $24^{\text {th }}$ May 2020, Published on $12^{\text {th }}$ July 2020

\begin{abstract}
Purpose of the Study: This study examines the correlation between metacognitive awareness, listening self-efficacy, and listening comprehension achievement of Islamic secondary school students in Indonesia.

Methodology: To obtain the data on students' metacognitive awareness, Metacognitive Awareness Listening Questionnaire (MALQ) and Metacognitive Awareness Inventory (MAI) was used. Data on students' self-efficacy was gained using the simplified version of Rahimi and Abedini's (2009) self-efficacy questionnaire (SEQ), The MorganJinks Student Efficacy Scale (MSES), and Motivated Strategies for Learning Questionnaire (MSLQ). Meanwhile, students' listening comprehension achievement was measured using the TOEFL Junior Test from Educational Testing Service. A total of 264 learners involved in this study.
\end{abstract}

Main Findings: The result of correlational analysis using Kendall Tau-b formula revealed that 1) there was no significant contribution of learners' metacognitive awareness toward their listening comprehension achievement, 2) students' listening self-efficacy has a very low correlation with their listening comprehension achievement, and 3) simultaneously, students' metacognitive awareness and their self-efficacy showed a very low reciprocal relationship with their listening comprehension.

Applications of the study: This study is relevant to senior secondary education in the Indonesian context in which English is the first foreign language. More specifically, it is relevant to schools whose students are multilingual and come from different backgrounds both economically and geographically.

Novelty/Originality of this study: Unlike other studies in a similar context that measures the general English academic achievement, this study focuses on a specific skill, listening comprehension. In addition, it uses two variables (metacognitive awareness and self-efficacy) outright as the predictors of students' listening comprehension achievement.

Keywords: Metacognitive Awareness, Listening Self-efficacy, Listening Comprehension Achievement, Listening Test, Individuals' Belief.

\section{INTRODUCTION}

Listening proficiency in English is one of the fundamental determinants of an individual's academic success (Demir, 2017), and a great number of English foreign language (EFL) learners oftentimes face distress in acquiring it. This fact frequently leads EFL learners to feel anxious when they are faced with a listening course. It is indeed highly anxietyprovoking for EFL learners if it is incomprehensible.

Listening comprehension instruction at school and university, which tends to focus on finishing the tasks instead of developing listening skills, might affect learners' listening self-efficacy and their ways to enhance their listening skills. Over the distinctive setting of learning, it has been discovered that students will in general discover listening is more troublesome than other second or unknown dialect abilities. They will also feel that listening turns into the most troublesome aptitude to increase (Goh, 2000). This negative conviction may emerge from the concept that listening is an inactive aptitude over which students have no control in fathoming it, it is conceivably strengthened by the sort of listening instruction the learners have been presented to both at school and at college (Simasngyaporn, 2016).

A preliminary study conducted by the researchers with a number of secondary school students in the Kediri district in Indonesia indicated that students' self-efficacy and their metacognition or learning strategies might contribute to their listening comprehension development. A number of students encountered several adversities in listening class. The issues range from the students' limited vocabulary, limited background knowledge, to confidence. Learners feel that a task they faced is either unfamiliar or too difficult for them. This anxiety might be strengthened by the wrong assumption that they have to grasp each word they listen to. In contrast, some students who have high self-efficacy believed that they could conquer any listening test. They believed in their knowledge and their own listening strategy that they have learned, and they were capable to develop their listening skill development. As a result, they enjoyed and made their pleasant atmosphere when they faced listening activity.

Self-efficacy is often being a superior indicator of accomplishment, including in listening proficiency, compared to prior accomplishments, skills, or knowledge. It is a person's perception, beliefs, and evaluation of performances and capability to carry out the specific task. According to Bandura (1997, as cited in Mills, Pajares \& Herron (2006), self- 
efficacy is individuals' belief about their capability to arrange and execute a task and to power over their musings, emotions, and activities required to produce given attainments. It is not dependent on one's abilities but instead on what one's beliefs, and may be accomplished with one's personal skill set. A person's degree of self- efficacy is thought to identify with the person's selection of exercises, exertion and determination in those activities (Kazemi, Khodabandehlou, and Jahandar, 2013). Self-efficacy provides an essential stimulant to discover and explore strategies and methods in listening class, so in order to raise students' intended skills, they can improve their self-efficacy and selfconfidence level.

Aside from the self-efficacy level, students' strategies used in acquiring the information they heard also play a significant role in developing their ideas and understanding when the listening section takes place. The strategies used in listening practice are called metacognition. Metacognition deals with mental processes, procedures of control, and adjustment of the language acquisition mechanism. Furthermore, students' strategies and methods they apply in learning, acquiring, and organizing knowledge influence their process to succeed in comprehending language skills (Rahimi \& Abedi, 2009; Cera, Mancini, and Antonietti, 2013). In other words, metacognitive strategy awareness is essential in managing EFL learners organizing a specific learning task. This metacognitive awareness helps students to take the test easier and less problematic, which in turn they can comprehend the language skill and proficiency better.

A number of researchers $\underline{(\mathrm{Li}, 2013}$; Rahimirad \& Zare-ee, 2015) assert that listening strategy, metacognitive strategy awareness, can be used to help students to predict the listening task and stimulate students' pre-assumption in catching up the knowledge and information they needed, so they are able to select and make an appropriate strategy to complete the tasks and give a meaning to what they listened to. Alwan, Asassfeh, and Shboul (2013) state that different listening metacognitive strategies used have a different contribution to the students' listening comprehension achievement process. In order to manage their performance and ability, students tend to get more focused on the difficulties that they faced in comprehending the language skill. Their satisfaction level of task result has a straight line with the metacognitive strategy awareness level that affects students' performance and interpretation. Eded (2017) states that students are able to develop metacognitive listening awareness on their own to a certain stage and it will rise higher if they are faced with a systematic metacognitive listening task and instruction.

Studies on metacognitive awareness, self-efficacy, and listening comprehension achievement have been conducted by previous researchers (Tabrizi and Saedi, 2015; Rahimi and Abedi, 2014; Travakoli, Shahraki, and Rezazadeh, 2012; Goh and $\mathrm{Hu}, 2013$ ). A study conducted by Tabrizi and Saedi (2015) involving 90 female learners of intermediate level of EFL learners at the Iran Language Institute revealed that learners' listening self-efficacy correlate positively to their listening autonomy and listening comprehension. In addition, Rahimi and Abedi's (2014) study investigating the interface of Iranian EFL learners' listening self-efficacy and the metacognitive awareness revealed that both variables positively correlated to each other. A similar result was pointed out by Travakoli, Shahraki, and Rezazadeh's (2012) study involving 66 Iranian intermediate and advanced-level students. The study yielded that the students' metacognitive awareness was positively correlated with their IELTS listening test scores. Another study involving 113 ESL Chinese learners conducted by Goh and Hu (2013) revealed that learners' metacognitive awareness scores have a meaningful positive link with their listening accomplishment.

Taking into account the aforementioned previous studies and given the cultural setting where the studies were conducted, the researchers investigated whether or not self-efficacy and metacognitive awareness contribute positively toward students' listening comprehension achievement in the Indonesia context. This study is essential in order to support and complete the findings of previous research. This is in line with Li's (2013) notion asserting that the study should be replicated and expanded with more different groups of learners and wider participants and variables. Furthermore, Kaya (2017) suggests further research to extend the study in order to identify whether metacognition and self-efficacy could improve listening performance.

\section{LITERATURE REVIEW}

\section{Metacognitive Awareness}

The term 'metacognition' was foremost introduced by John Flavel, an American psychologist in 1978 (Goudarzi \& Ghoonsooly, 2014). A number of researchers (Hennesy, 1999; Kuhn \& Dean, 2004, and Martinez, 2006), who worked in the field of cognitive psychology defined metacognition as the way of people's thinking to monitor and control their learning processes and activities which become effective tools for helping them organize and regulate their method in attacking the problems. Metacognition helps people enable their thinking to build a particular strategy used in solving a problem then retrieving a similar strategy in a new context of learning or problem (Kuhn \& Dean, 2004).

According to Schunk (2012), metacognition is composed of two aspects of related competencies namely understanding the potency and how to use the potency. Understanding potency means that people should know their ability, strategy, and their needs to perform in a task given. This kind of aspect covers developing information, finding the main idea, using trial and error, organizing the materials, etc. Meanwhile, understanding how to use potency refers to people's awareness to know how and when their potency and strategy are used to obviously ensure they can perform perfectly in the tasks. This activity covers checking the understanding of the materials, predicting the learning result, planning and revising the tasks, and managing time. In other words, metacognition is a key tool to think critically which defined as 
people's awareness and control over their own thinking involving high order active thinking processes to be successful in language learning (Schraw, 1998; Kuhn as cited in Schunk, 2012). According to Vandergrift et al., (2006), five components influencing metacognitive strategy include individual knowledge, planning and evaluation, mental interpretation, problem-solving, and directed attention.

Metacognitive strategies connect the way people think about the learning process, planning, monitoring, and selfevaluation and regulation after completing the learning activity, so the goal of teaching and learning process can be reached (Alwan, Asassfeh, and Al-Shboul, 2013). Metacognitive strategies become one of the essential strategies that learners should know as they help them to enhance their listening as well as reading comprehension skill (Safitri, 2016).

\section{Self-efficacy}

Self-efficacy refers to individuals' beliefs in ones' own ability to accomplish something successfully. Pintrich and Schunk (2002) believed that self-efficacy is different from self-concept in which it depicts a more general conviction about capability. Self-efficacy focuses on particular and situational judgments of capabilities much more than selfconcept. According to Bandura (1994), self-efficacy determines how people feel, think, propel, and comport themselves. A high sense of self-efficacy will improve people's performance and personal being in a number of ways which means that individuals with high beliefs in their capacity to accomplish a difficult task as challenged to be mastered rather than as threats to be kept it at the distance. It is a common presumption that people who have a high level of self-efficacy will get better achievements and performance than those with a lower level of self-efficacy beliefs. Self-efficacy is the basis of self-confidence and motivation and it plays an efficacious role in establishing the individuals' decision making, the attempt they will devote to the challenge and the level of anxiety or confidence they will bring to the task at hand. Students' sense of self-efficacy affects their academic performance. Students with a high sense of academic self-efficacy have been proven to lead to a higher level of accomplishment and success, and undertake challenging tasks willingly with demonstrating low anxiety level (Mills, Pajares and Herron, 2006).

According to Bandura (1994), a personal belief of self-efficacy is created through four primary sources of impact; mastery experiences, vicarious experiences, social persuasion, and psychological states. Mastery experiences are the most influential of the other sources and are the most powerful method to build a sense of efficacy (Bandura, 1994, p. 2). When someone beliefs they can accomplish something previously, she could be expected to have a strong sense of efficacy and put forthcoming effort in the same area to create positive feedback, and vice versa. Vicarious experience a situation when individuals learn that they have the capability to perform and execute a specific task by observing the other success on a similar task that they want to acquire. 'Seeing other people succeed or fail in a task can either raise or lower an individual's self-efficacy in his/her own capabilities' (Dodds, 2011, p. 21). The competent models transmit knowledge and teach one effective skill and strategies to manage his/her demand (Bandura, 1994).

The third factor that might affect one's efficacy is social persuasion, a lesser source of self-efficacy. People are likely to mobilize greater efforts and sustain them. They would exert effort in tasks more than those who have self-doubt (Bandura, 1994). In this case, people are persuaded verbally. Someone who persuades them needs to have high credibility in the field or subject that the others want to acquire. The most relevant form of verbal persuasion in the educational realm is in the form of feedback. Simasangyaporn (2016) argues that the feedback provided by the teacher contributes a greater sense of self-efficacy. The last affecting factor of one's efficacy, according to Bandura (1994), is psychological states, i.e., how individuals are influenced by their stress reactions and tension in their performance. People who have a high sense of efficacy tend to view their states as an energizing facilitator of performance. In other words, people who have high self-efficacy may consider their self-arousal states as a sign to prepare themselves for what they will encounter in the next.

\section{Listening Comprehension}

Listening comprehension is a complicated problem-solving activity that involves a lot of processes (Byrnes, 1984, as cited in Osada, 2004); recognizing and perceiving sounds, comprehending words and grammatical structures, interpreting stress and intonations, and interpreting all based on the context of the utterances immediately. To comprehend the spoken message, it has to involve receptive, constructive, and interpretive cognitive aspects. Brown (2001) states listening is an activity that takes efforts than hearing in which hearing is a psychological process involving vibration voice in-ear and the firing of audio electro-chemical impulses from the ear to the central auditory system. On the other hand, listening requires greater attention to and making sense of what we hear.

As a complex activity, in the listening process, learners do not merely receive the sounds and transmit to the brain but also need strategies. They should turn the complex listening activity into the effective one to make it easy to comprehend the context and meaning. Anderson and Lynch (2003) state that effective listening in face-to-face conversation incriminates a multiplicity of skills which comprise four steps: 1) the spoken signals have to be recognized from the midst of surrounding sound, which requires the listeners' ability to identify, as Nunan (1991) asserted, how many the speakers, how quickly they speak, and what types of accent they have, 2) the speech has to be fragmented into units as known words, 3) the sentence structure of the utterances has to be grasped and the speaker's intended meaning has to be understood, and 4) linguistic knowledge has to be applied to formulate a right and proper reaction to what has been said. 


\section{RESEARCH METHOD}

\section{Research Design and Participants}

In conducting this study, correlational design was applied. It was intended to determine and measure the link between students' metacognitive awareness, listening self-efficacy, and listening comprehension achievement using the degree of correlation namely the correlation coefficient. It was conducted at one of State Islamic Secondary Schools in East Java, Indonesia, involving 264 students as the participants ( 82 males and 182 females) aged between 15 to 17 years old. Most of the students are multilingual, speaking Javanese as their mother tongue and Indonesian (or Bahasa Indonesia) as their second language. English is the main foreign language they are learning. They come from rural and urban areas with different socioeconomic backgrounds: low, middle, and high.

\section{Research Instruments}

To obtain the data on the students' listening metacognitive awareness, a closed-ended questionnaire was used. The questionnaire was adopted and adapted from the Metacognitive Awareness Listening Questionnaire or MALQ (Vandergrift, et. al., 2006) and Metacognitive Awareness Inventory or MAI (Schraw, \& Dennison, 1994). Before being used, the questionnaire was piloted to find out its validity and reliability. The pilot study revealed that the Cronbach Alpha value was 0.793 , indicating that the instrument was acceptable and reliable to test the metacognitive awareness of students. The questionnaire comprised 25 items and was developed based on five sources of metacognitive awareness, that is planning or evaluation (8 items), directed attention (7 items), personal knowledge (4 items), mental translation (2 items), and problem-solving (4 items).

In gaining the data on students' listening self-efficacy, the researchers utilized a close-ended questionnaire. The questionnaire was adapted from Children's Perceived Academic Self-efficacy subscale from The Morgan-Jinks Student Efficacy Scale or MJSES (Jinks \& Morgan, 1999), Self-efficacy subscale from the Motivated Strategies for Learning Questionnaire or MSLQ (Pinrtrich and De Groot, 1990), and Rahimi and Abedini's (2009) self-efficacy questionnaire (SEQ). It was piloted to check the validity and reliability before being distributed to the research participants. The reliability of the questionnaire was very good as indicated by the Cronbach Alpha value 0.811 . In total, the questionnaire consisted of 25 items which comprised four main sources of self-efficacy influence; mastery experiences (10 items), vicarious experiences (6 items), social persuasion (5 items), and psychological states (4 items). Both the metacognitive awareness questionnaire and the listening efficacy questionnaire were in the form of a four-point Likert-scale ranging from 1 (strongly disagree) to 4 (strongly agree).

To measure the participants' listening comprehension achievement, a multiple-choice listening test consisting of 29 items was employed. The test was adapted from Listening Comprehension Section test from TOEFL Junior Test from ETS (Educational Testing Service, 2012). The listening test consists of three sections namely: classroom instruction, short conversation, and academic listening.

\section{Data Collection}

In this study, the participants were spread in 8 different parallel classes. To obtain the required data, the researchers came to the participants' classrooms to distribute both questionnaires and to conduct the listening test. Overall, the researchers took three weeks in the data collection process. Metacognitive awareness questionnaire was distributed in the first week, followed by the listening test on the second week, and self-efficacy data collection in the final week.

\section{Data Analysis}

In analyzing all quantitative data and in dealing with computing manner, the researchers were equipped with a statistical software called Social Package of Social Science (SPSS) 21.0 and Microsoft Excel 2016. Prior to performing the correlational analysis, the normality of data distribution of the obtained data was tested utilizing Kolmogorov-Smirnov with Lilliefors significance correction. This process was undertaken since it affected the correlation formula to use.

Table 1: Test result of data normality distribution using Kolmogorov-Smirnov

\begin{tabular}{lllllll}
\hline & \multicolumn{3}{l}{ Kolmogorov-Smirnov $^{\text {a }}$} & \multicolumn{3}{c}{ Shapiro-Wilk } \\
\cline { 2 - 7 } & Statistic & Df & Sig. & Statistic & Df & Sig. \\
\hline Listening test & .097 & 264 & $\mathbf{. 0 0 0}$ & .970 & 264 & .000 \\
\hline Self-efficacy & .084 & 264 & $\mathbf{. 0 0 0}$ & .983 & 264 & .003 \\
\hline Metacognitive & .066 & 264 & $\mathbf{. 0 0 7}$ & .989 & 264 & .048 \\
\hline A. Lilliefors Significance Correction & & & & \\
\hline
\end{tabular}

The result of the normality test, as shown in Table 1, indicated that the data of the three variables were not normally distributed $(\mathrm{p} \leq 0.05)$. This condition led the researchers to utilize Kendall Tau-b formula in finding out the correlation between variables. In determining the correlation between variables, the researchers applied standards of coefficient correlation as shown in table 2 . 
Table 2: Standard of coefficient correlation

\begin{tabular}{ll}
\hline Coefficient Correlation & Degree of correlation \\
\hline $0,00-0,199$ & Very Low Correlation \\
\hline $0,20-0,399$ & Low Correlation \\
\hline $0,40-0,599$ & Moderate Correlation \\
\hline $0,60-0,799$ & High Correlation \\
\hline $0,80-1,000$ & Very High Correlation \\
\hline
\end{tabular}

In order to know the contribution magnitude of the variable, correlation contribution (R) formula $R=r^{2} \times 100$ was used, in which $\mathrm{R}$ refers to coefficient determination and $\mathrm{r}$ refers to coefficient correlation. The result of the analysis illustrated the percentage of coefficient correlation determination of the predictor variable that shared with the criterion variables.

\section{FINDINGS AND DISCUSSION}

Prior to presenting the correlation between the three variables, the following is the result of the descriptive analysis (see table 3).

Table 3: The descriptive statistics of students' metacognitive awareness, self-efficacy, and listening test

\begin{tabular}{lllllllll}
\hline & N & R & Min & Max & Sum & Mean & Std. Deviation & Variance \\
\hline Metacognitive & 264 & 40 & 56 & 96 & 19977 & 75.67 & 7.372 & 54.351 \\
Valid N (Listwise) & 264 & & & & & & & \\
\hline Self-Efficacy & 264 & 40 & 46 & 86 & 16482 & 62.43 & 7.745 & 59.988 \\
Valid N (Listwise) & 264 & & & & & & & \\
\hline Listening Test & 264 & 25 & 2 & 27 & 3310 & 12.54 & 5.148 & 26.500 \\
Valid N (Listwise) & 264 & & & & & & & \\
\hline
\end{tabular}

The table displays that the mean of students' metacognitive awareness score $(\mathrm{N}=264)$ is 75.67 . The lowest score is 56 , the highest is 96 , and the data interval is 40 , which mean that there is a lengthy gap between the highest and the lowest scorers. Regarding the students' self-efficacy, the table points out that the mean score is 62.43 and the standard deviation is 7.745, indicating that the data was well-spread as the mean score is higher than the standard deviation. The range between the lowest to the highest is nearly twofold, 46 to 86 . In addition, the mean score of students' listening test is 12.54 in which the lowest score is 2 and the highest is 27 from a total of 29 questions. Although the data is well-spread, the interval between the lowest and the highest is definitely lengthy, 25 points.

\section{The Magnitude of Metacognitive Awareness Contribution toward Students' Listening Comprehension} Achievement

The result of Kendall's tau-b correlational analysis shows nearly no correlation between students' metacognitive awareness and their listening comprehension achievement (see table 4).

Table 4: Correlation between students' metacognitive awareness and listening comprehension achievement

\begin{tabular}{|c|c|c|c|c|}
\hline & & & Listening test & Metacognitive \\
\hline \multirow{6}{*}{ Kendall's tau_b } & \multirow{3}{*}{ Listening test } & Correlation Coefficient & 1.000 & -.014 \\
\hline & & Sig. (2-tailed) & -1 & .753 \\
\hline & & $\mathrm{N}$ & 264 & 264 \\
\hline & \multirow{3}{*}{ Metacognitive } & Correlation Coefficient & -.014 & 1.000 \\
\hline & & Sig. (2-tailed) & .753 & . \\
\hline & & $\mathrm{N}$ & 264 & 264 \\
\hline
\end{tabular}

Table 4 exhibits the Sig. (2-tailed) value is 0.753 , greater than 0.05 , which means no significant correlation between variables. It also shows that the correlation coefficient is $-0.014(\mathrm{r}=-.014)$ in which, according to the correlation coefficient index, the two variables have a very weak negative correlation. In other words, in this study, students' metacognitive awareness plays nearly no contribution to their listening comprehension achievement. It is not the most determinant factor in achieving listening proficiency.

This finding supports and at the same time is in contrast to previous studies. A study undertaken by $\underline{\text { Astini (2017) }}$ revealed similar results in which metacognitive awareness did not have any correlation in influencing the listening comprehension achievement of senior high school students $(\mathrm{r}=.101, \mathrm{p}=.332)$. This is corroborated with an argument that other factors affecting students' listening comprehension are concentration, topic interest, attention, expectation, and sufficient knowledge (Khalifa, as cited in Astini, 2017). In addition, Wang and Treffers-Daller's (2017) study reinforced that vocabulary size is the strongest predictor of learners' listening comprehension, followed by general language proficiency, while metacognitive awareness is less important. 
On the contrary, the result of Travakoli, Shahraki, and Rezazadeh's (2012) study revealed that learners' metacognitive awareness was positively correlated to their IELTS listening score $(\mathrm{r}=.398, \mathrm{p}=.001)$. This finding was amplified by previous researchers illuminating that metacognitive awareness plays an important role to regulate students' listening skills since it had a positive correlation with listening skill performance and gave benefit to the learners to complete the task (Li, 2013; Sahragrard et al., 2015).

\section{Correlation between Listening Self-Efficacy and Listening Comprehension Achievement}

To what extent students' self-efficacy contributes to their listening comprehension achievement can be noticed via table 5. The Sig. value 0.015 , as the table reveals, indicates that the first variable is significantly correlated to the second one. In other words, the higher the students' self-efficacy is, the higher their listening proficiency is.

Table 5: Correlation between students' self-efficacy and their listening comprehension achievement

\begin{tabular}{|c|c|c|c|c|}
\hline & & & $\begin{array}{l}\text { Listening } \\
\text { test }\end{array}$ & Self-efficacy \\
\hline \multirow{6}{*}{ Kendall's tau_b } & \multirow{3}{*}{ Listening test } & Correlation Coefficient & 1.000 & $.105^{*}$ \\
\hline & & Sig. (2-tailed) & - & .015 \\
\hline & & $\mathrm{N}$ & 264 & 264 \\
\hline & \multirow{3}{*}{ Self-efficacy } & Correlation Coefficient & $.105^{*}$ & 1.000 \\
\hline & & Sig. (2-tailed) & .015 & . \\
\hline & & $\mathrm{N}$ & 264 & 264 \\
\hline
\end{tabular}

Regarding the magnitude of the contribution, the value of correlation coefficient $0.105(\mathrm{r}=0.105)$ indicates that students' listening self-efficacy plays a very weak or low contribution to students' listening comprehension achievement. This is in contrast to previous studies conducted by Lestari (2017) and Mills, Pajares, and Herron (2006). Lestari (2017) uncovered that students' listening self-efficacy had no significant correlation with listening comprehension achievement. In addition, Mills, Pajares, and Herron's (2006) inquiry involving 95 college students in the French listening course setting revealed that listening self-efficacy didn't have any significant correlation with listening proficiency. However, the result of the present study corroborates Kazemi, Khodabandehlou, and Jahandar's (2013) finding indicating that students' self-efficacy and their listening test achievement had a high and significant reciprocal relationship. The result of Kazemi, Khodabandehlou, and Jahandar's (2013) study and the present study support Bandura's (1994) theory stating that self-efficacy level has a positive line or positive bond with people activities.

\section{Multiple Correlations between Students' Metacognitive Awareness, Self-Efficacy, and Listening Comprehension} Achievement

The data below answers the question of whether students' metacognitive awareness and listening self-efficacy simultaneously have a significant contribution toward their listening comprehension achievement.

Table 6: Multiple correlation between metacognitive awareness, self-efficacy and listening comprehension achievement

\begin{tabular}{lccccccccc}
\hline $\begin{array}{c}\text { Mode } \\
\mathbf{l}\end{array}$ & $\mathbf{R}$ & $\begin{array}{c}\mathbf{R} \\
\text { Square }\end{array}$ & $\begin{array}{c}\text { Adjusted R } \\
\text { Square }\end{array}$ & $\begin{array}{c}\text { Std. The } \\
\text { error of the } \\
\text { Estimate }\end{array}$ & \multicolumn{5}{c}{ Change Statistics } \\
\cline { 5 - 9 } & \multicolumn{2}{c}{$\begin{array}{c}\text { R Square } \\
\text { Change }\end{array}$} & $\begin{array}{c}\mathbf{F} \\
\text { Change }\end{array}$ & $\begin{array}{c}\text { df } \\
\mathbf{1}\end{array}$ & $\begin{array}{c}\text { Sig. F } \\
\text { Change }\end{array}$ \\
\hline 1 & $.187^{\mathrm{a}}$ & .035 & .028 & 5.076 & .035 & 4.738 & 2 & 261 & .010 \\
\hline a. Predictors: (Constant), Metacognitive, Self-Efficacy \\
\hline
\end{tabular}

The significance value (sig. F Change) 0.010 , as pointed out by table 6 , indicates that both metacognitive awareness and listening self-efficacy significantly correlate with listening comprehension achievement simultaneously. The coefficient correlation (R) 0.187 signifies that the magnitude of the bond is very weak. It is also clear that $r$ obtained is greater than $r$ table $(r=.187>\mathrm{r} 200=0.138)$ representing that both variables simultaneously correlate to students' listening comprehension achievement.

Compared to the result of previous studies, the present study supports a study by Kaya (2017) suggesting that students with high self-efficacy beliefs and listening strategies tend to have high achievement in their listening comprehension performance. In addition, a study by Ghonsooly, Khajavy, and Mahjoobi (2014) revealed that self-efficacy and metacognition are positive predictors in affecting individuals' performance $(\mathrm{p}=.001)$.

\section{CONCLUSION}

The result of the current study is in contrast and at the same time corroborates the previous studies conducted in a different cultural setting. In this study, students' metacognitive awareness does not make any significant contribution to students' listening comprehension achievement and students' listening self-efficacy has a very low correlation with their listening comprehension achievement. Furthermore, students' metacognitive awareness and their self-efficacy, when 
they are correlated simultaneously, showed a very low relationship with their listening comprehension. In short, albeit the magnitude of the bond is low, the reciprocal link between variables does exist.

Taking the results of the current study into account, the development of students' metacognitive awareness and selfefficacy should be part of a teacher's intent. This is because a growing number of studies supported the notion that metacognitive awareness and self-efficacy for listening can be increased through classroom instruction. An approach such as the use of e-portfolios could be adopted to develop metacognitive awareness (Altıok, Bașer, Yukselturk, 2019) and degree of self-efficacy might be enhanced by activities that provide the opportunity for adult students to verbalize and talk about the strategy they implement (Graham, 2011). Teachers' feedback concentrating on strategy use is a determinant aspect in substantiating learners' concept of how listening proficiency can be restrained.

\section{LIMITATION AND THE STUDY FORWARD}

This study took place in a micro-scale context, i.e., a state Islamic senior high school. Therefore, the result of this study is not adequate to generalize the contribution of metacognitive awareness toward students' listening comprehension achievement and their listening self-efficacy in a different context. In addition, the findings of this study might be influenced by other unidentifiable factors, such as learning styles, intelligence, or previous background knowledge. It is recommended that future similar studies could be conducted in different education levels, or in the culturally and geographically different school contexts.

\section{ACKNOWLEDGEMENT}

This is self-funded research and free from any conflict of interest. Even though, the authors would like to express their gratitude to the anonymous reviewers who have patiently reviewed this paper and provided a number of constructive feedbacks. As such, the authors could improve the readability level of this paper for the academic realm.

\section{AUTHORS CONTRIBUTION}

In this study, designing the research instrument, collecting the data, and analyzing the data were conducted by the second author. In doing so, he was assisted and guided by the first author. Organizing the research report into the raw draft of the scientific article was also done by the first author. Meanwhile, the third, fourth, and fifth authors were in charge of proofreading and refining the draft thoroughly into a readily published manuscript.

\section{REFERENCES}

1. Al-Alwan, A., Asassfeh, S., Al- Shboul, Y. (2013). EFL Learners' Listening Comprehension and Awareness of Metacognitive Strategies: How Are They Related? International Education Studies, 6 (9), 31-39. https://doi.org/10.5539/ies.v6n9p31

2. Altıok, S., Başer, Z., Yukselturk, E. (2019). Enhancing metacognitive awareness of undergraduates by using an e-educational video environment. Computers \& Education, 139. 129-145. https://doi.org/10.1016/j.compedu.2019.05.010

3. Anderson, A. \& Lynch, T. (2003). Listening. Oxford: Oxford University Press.

4. Astini, D. (2017). The Correlation between Metacognitive Strategies and Listening Comprehension of the Eleventh Grade Students of SMA Muhammadiyah Palembang. [Unpublished Undergraduate Thesis]. UIN Raden Fatah Palembang.

5. Bandura, A. (1994). Self-Efficacy. In V. S. Ramachandran (Ed.), Encyclopedia of Human Behavior (Vol. 4, 71 81). New York: Academic Press.

6. Brown, S. (2001). Listening Myths: Applying Second Language Research to Classroom Teaching. Michigan ELT.

7. Cera, R., Mancini, M., Antonietti, A. (2013). Relationship between Metacognition, Self-efficacy and Selfregulation in Learning. ECSP Journal, 7, 115-141. https://doi.org/10.7358/ecps-2013-007-cera

8. Demir, S. (2017). An Evaluation of Oral Language: The Relationship between Listening, Speaking and Selfefficacy. Universal Journal of Educational Research, 5(9), 1457-1467. https://doi.org/10.13189/ujer.2017.050903

9. Dodds, J. (2011). The correlation between self-efficacy belief, language performance and integration amongst Chinese immigrant newcomers [Unpublished Master Thesis]. Hamline University.

10. Eded, J. (2017). Metacognitive Awareness in EFL Listening. [Unpublished Master Thesis]. J.J. Strossmayer University of Osijek.

11. Educational Testing Service. (2012). Practice test for the TOEFL Junior Standard Test.

12. Ghonsooly et al. (2014). Self-efficacy and Metacognition as Predictors of Iranian teacher trainees' academic performance: a path analysis approach. Procedia-social and behavioral science, 98(2014), 590-598. https://doi.org/10.1016/j.sbspro.2014.03.455

13. Goh, C. C. M. (2000). A Cognitive Perspective on Language Learners' Listening Comprehension Problems. System, 28(1), 55-75. https://doi.org/10.1016/S0346-251X(99)00060-3 
14. Goh, C. C. M. \& Hu, G. (2013). Exploring the relationship between metacognitive awareness and listening performance with questionnaire data, Language Awareness, 23(3), 1-20. https://doi.org/10.1080/09658416.2013.769558

15. Goudarzi, E \& Ghonsooly, B. (2014). The Relationship between Metacognitive Awareness and Self-Efficacy and Their Effects on Test Performance of Iranian EFL Learners. International Journal of Language Learning and Applied Linguistics World, 6(1), 296-305.

16. Graham, S. (2011). Self-efficacy and academic listening. Journal of English for Academic Purposes, 10. 113117. https://doi.org/10.1016/j.jeap.2011.04.001

17. Hennessey, M. G. (1999). Probing the dimensions of metacognition: Implications for conceptual change teaching-learning. Paper presented at the annual meeting of the National Association for Research in Science Teaching, Boston, MA.

18. Jinks, J., \& Morgan, V. (1999). Children's Perceived Academic Self -Efficacy: An Inventory Scale. The Clearing House, 72(4), 224-230. https://doi.org/10.1080/00098659909599398

19. Kaya, T. (2017). A Follow-Up Study on Listening Strategy Use and Self-Efficacy in Relation to Listening Proficiency in EFL. The Economic Review of Toyo University, 42(2) 155-166. http://id.nii.ac.jp/1060/00008527/

20. Kazemi, M., Khodabandehlou, M., \& Jahandar, S. (2013). The Impact of Self-Efficacy on Iranian Intermediate EFL Learner's Listening Comprehension. Indian Journal of Fundamental and Applied Life Sciences, 3(3), 705715.

21. Kuhn, D. \& Dean, D. (2004). A bridge between cognitive psychology and educational practice. Theory into Practice, 43(4), 268-273. https://doi.org/10.1207/s15430421tip4304_4

22. Lestari, D. (2017). The Correlation Between Self-Efficacy Concerning Listening Skill and Listening Comprehension of the Eleventh Grade Students of SMA Negeri 1 Pemulutan Selatan. [Unpublished Undergraduate Thesis]. UIN Raden Fatah Palembang, Indonesia.

23. Li, W. (2013). A Study of metacognitive Awareness of Non-English Majors in L2 Listening. Journal of Language Teaching and Research, 4(3), 504-510. https://doi.org/10.4304/jitr.4.3.504-510

24. Martinez, M. E. (2006). What is metacognition? Phi Delta Kappan, 696-699. https://doi.org/10.1177/003172170608700916

25. Mills, N., Pajares, F., Herron, C. (2006). A Reevaluation of the Role of Anxiety: Self-efficacy, Anxiety, and Their Relation to Reading and Listening Proficiency. Foreign Language Annals, 39(2), 276-295. https://doi.org/10.1111/j.1944-9720.2006.tb02266.x

26. Nunan, D. (1991). Language Teaching Methodology: A textbook for teachers. New York: Prentice Hall.

27. Osada, N. (2004). Listening Comprehension research: A brief review of the Past Thirty Years. Dialogue, 3, 5566.

28. Pintrich, P. R., \& De Groot, E. V. (1990). Motivational and self-regulated learning components of classroom academic performance. Journal of Educational Psychology, 82(1), 33-40. https://doi.org/10.1037/00220663.82.1.33

29. Pintrich, P. R., \& Schunk, D. H. (2002). Motivation in education: Theory, research, and applications ( $2^{\text {nd }}$ ed.). Upper Saddle River, NJ: Prentice Hall.

30. Rahimi, A., \& Abedini, A. (2009). The Interface between EFL Learners' Self-Efficacy Concerning Listening Comprehension and Listening Proficiency. Novitas Royal, 3(1), 14-28.

31. Rahimi, M., \& Abedi, A. (2014). The Relationship between Listening Self-Efficacy and Metacognitive Awareness of Listening Strategies. Procedia - Social and Behavioral Sciences, 98, 1454-1460. https://doi.org/10.1016/j.sbspro.2014.03.565

32. Rahimirad, M., \& Zare-ee, A. (2015). Metacognitive Strategy Instruction as a Means to Improve Listening Selfefficacy among Iraninan Undergraduate Learners of English. International Journal of Instruction, 8(1), 117132. https://doi.org/10.12973/iji.2015.819a

33. Safitri, M. (2016). The Relationship among Metacognitive Learning Strategy, Vocabulary Mastery, and Reading Comprehension. [Unpublished Master Thesis]. Sanata Dharma University, Indonesia.

34. Sahragrard, R., Kushki, A., Miri, M. \& Mahmooudi, F. (2015). The Metacognitive Awareness Listening Questionnaire as a Metacognitive-Raising Tool: Does It Works? Global Journal of Foreign Language Teaching. 5(1), 101-113. https://doi.org/10.18844/gjflt.v5i0.51

35. Schraw, G. \& Dennison, R.S. (1994). Assessing metacognitive awareness. Contemporary Educational Psychology, 19, 460-475. https://doi.org/10.1006/ceps.1994.1033

36. Schraw, G. (1998). Promoting general metacognitive awareness. Instructional Science, 26(1-2), 113-125. https://doi.org/10.1023/A:1003044231033

37. Schunk, D.H. (2012). Learning Theories: An Educational Perspective. $6^{\text {th }}$ edition (Indonesian translation version). Pustaka Pelajar Press, Indonesia.

38. Simasangyaporn, N. (2016). The Effect of Listening Stategy Instruction on Thai learners' Self-efficacy, English Listening Comprehension and Reported Use of Listening Stategies. [Unpublished doctoral dissertation]. University of Reading. 
39. Tabrizi, H.M., \& Saedi, M. (2015). The Relationship among Iranian EFL Learners' Self-efficacy, Autonomy and Listening Comprehension Ability. English Language Teaching, 8(12), 158-169. https://doi.org/10.5539/elt.v8n12p158

40. Travakoli, M., Shahraki, S. H., and Rezazadeh, M. (2012). The Relationship between Metacognitive Awareness and EFL Listening Performance; Focusing on IELTS Higher and Lower Scores. Journal of language teaching and learning, 2, 24-37.

41. Vandergrift, L., Goh, C., Mareschal, \& Tafaghodatari, M.H. (2006). 'The Metacognitive Awareness Listening Questionnaire (MALQ): Development and Validation', Language Learning, 56, 431-62. https://doi.org/10.1111/j.1467-9922.2006.00373.x

42. Wang, Y., Treffers-Daller, J. (2017). Explaining listening comprehension among L2 learners of English: The contribution of general language proficiency, vocabulary knowledge and metacognitive awareness. System 65. 139-150. https://doi.org/10.1016/j.system.2016.12.013 